\title{
The Effectiveness of Lavender Aromatherapy on Blood Pressure among Elderly with Essential Hypertension
}

\author{
Dwi Yunita Rahmadhani* \\ Study Program of Bachelor and \\ Professional in Nursing, STIKes \\ Baiturrahim Jambi, Jambi 36135, \\ Indonesia \\ ${ }^{*}$ Correspondence: Dwi Yunita \\ Rahmadhani \\ Study Program of Bachelor and \\ Professional in Nursing, STIKes \\ Baiturrahim Jambi, Jambi 36135, \\ Indonesia. \\ Phone: 6281279104943 \\ Email: dwi.azkaya@gmail.com
}

Volume 1(1), 1-8

(c) The Author(s) 2022

http://dx.doi.org/10.55048/jpns.v111.8

e-ISSN 2827-8100

p-ISSN 2827-8496

Received : January 12, 2022

Revised : January 17, 2022

Accepted : January 18, 2022

Published: January 20, 2022

\section{(i) ()}

This is an Open Access article distributed under the terms of the Creative Commons Attribution-NonCommercial 4.0 International License.

\begin{abstract}
Background: Hypertension is a condition in which the systolic blood pressure is more than $120 \mathrm{mmHg}$, and the diastolic pressure is more than $80 \mathrm{mmHg}$. Lavender aromatherapy is a way to cure sickness which uses essential oil.

Purpose: The purpose of this study is to analyse the effect of lavender aromatherapy on the changes in blood pressure in the Elderly with essential hypertension

Methods: This study used a pra-experiment pretest and posttest design where the measurement of blood pressure is done twice before the lavender aromatherapy is given (pretest) and after the lavender aromatherapy is given (posttest). The population of this study is the patients with essential hypertension in the work area of one of the Public Health Centers in Jambi, Indonesia in 2018 which is 627 patients. Meanwhile, the sample used in this study is Purposive Sampling. The method used in this study is univariate and bivariate data analysis using T-Test.

Results: Statistical test result shows that there was a significant effect of giving lavender aromatherapy on changes in blood pressure of patients with essential hypertension with $p<0.05$; systole $(p=0.001)$ and diastole $(p<0.001)$.

Conclusions: The use of alternative lavender aromatherapy as a therapy used to lower blood pressure in patients with essential hypertension. It is suggested to researchers who are interested to examine this topic of the effect of lavender aromatherapy on blood pressure in patients with essential hypertension to do further research in the same scope with a different variable.
\end{abstract}

Keywords: blood pressure; elderly; lavender aromatherapy

\section{INTRODUCTION}

Almost in every country, hypertension is ranked as the most frequently encountered disease. World Health Organization (WHO) data shows that there are almost one billion people is diagnosed with hypertension globally, this number is estimated to increase by $50 \%$ in 2025 . From one billion patients, $33.3 \%$ of patients are in developed countries. Meanwhile, the other $66.7 \%$ is in developing countries including Indonesia (Kusyati et al., 2018). There is $21 \%$ of hypertension patients in Indonesia and

Ramadhani, D. Y. (2022). The Effectiveness of Lavender Aromatherapy on Blood Pressure among Elderly with Essential Hypertension. The Journal of Palembang Nursing Studies. 1(1):1-8. http://dx.doi.org/10.55048/jpns.v1i1.8 
mostly are undetected. According to Riskesdas (2018), the prevalence of hypertension based on doctor diagnosis for people under 18 years old in Jambi province is ranked 22 out of 33 provinces in Indonesia with a prevalence of less than $6.5 \%$.

Hypertension is a condition in which the systolic blood pressure is more than 120 $\mathrm{mmHg}$, and the diastolic pressure is more than $80 \mathrm{mmHg}$. Hypertension often caused a change in blood pressure which resulted in much higher blood pressure. The initial treatment for hypertension is critical because it could prevent complications on other organs such as the heart, kidney, and brain (Muttaqin, 2008). Hypertension could be divided into three types based on its causes which are essential hypertension which the cause is not known, secondary hypertension which is caused by another disease, and primary hypertension which is found in $90 \%$ of patients, while the rest $10 \%$ is caused by secondary hypertension (Padila, 2013). The prolonged and immediate effects of hypertension need to be treated thoroughly comprehensive. Hypertension caused a high number of morbidity and mortality. Hypertension is the highest cause of mortality in the world with 7.1 million people or $13 \%$ of total mortality. The prevalence in developed and developing countries is almost the same size as each other. The development of hypertension is slow but has dangerous potential (Herliawati \& Ramadhani, 2014).

There are two ways hypertension could be treated which are pharmacology and nonpharmacology. Pharmacology treatment is a treatment that used medicine such as diuretic, beta-blocker, central sympatholytic, alfa-blocker, arteries vasodilator, calcium canal blocker, Angiotensin-converting enzyme (ACE) inhibitor, and antagonist receptor type I angiotensin II. Besides that, there is also alternative treatment (non-pharmacology treatment) which includes 1) acupressure (needleless acupuncture), 2) Chinese herbal medicine, 3) juice therapy, 4) herbal therapy, 5) massage, 6) yoga, 7) lavender aromatherapy, 9) respiration and relaxation, 9) mind and body treatment, biofeedback or meditation, hypnosis, and 10) home care (Adhistya et al., 2013).

Lavender aromatherapy is a way to cure sickness which uses essential oil. Lavender aromatherapy works not only by affecting physically but also emotionally. The benefit of lavender aromatherapy is reducing anxiety, joint pain, high blood pressure, heart frequency, metabolic rate, insomnia, stress, and increased melatonin and serotonin. Aromatherapy could soothe people physically, mentally, and spiritually, creating a peaceful ambience, and holding off anxiety (Jaelani, 2017). The efficacy of each aromatherapy needs to be considered in choosing the type of aromatherapy that will be used in massage. Lavender essential oil the widely used in massage because of its content that has aldehyde which is only $2 \%$ irritative and non-toxic. The Lavender flower works smoothly on skin and gives a therapeutical effect (Price \& Price, 2011; Koesoemardiyah, 2012).

Based on the study done by Herliawati \& Ramadhani. (2014), shows that from 3 respondents $(33,3 \%)$ diagnosed with severe hypertension, 4 respondents (45\%) with mild hypertension, and 2 respondents $(22,2 \%)$ with moderate hypertension. Lavender essential oil is one of the safest oils which has strong anti-septic power, anti-virus, and mosquitoes' repellent. Therefore, it is widely used to treat infection in the lung, spine, vagina, skin, ease muscle pain, headache, and is used online due to its power to accelerate the healing of skin cells which burned because of sunlight or wound. Having a massage or taking bath using lavender essential oil is used to increase immunity because of its rich efficacy. Lavender essential oil is one of the most popular essential oil in aromatherapy (Koesoemardiyah, 2012).

Based on the study done by Soraya (2014), is known that the average systolic and diastolic pressure before lavender aromatherapy is given is $154.55 \mathrm{mmHg}$ and $95 \mathrm{mmHg}$. Meanwhile, the average systolic and diastolic pressure after the treatment is given is 128.89 $\mathrm{mmHg}$ and $85 \mathrm{mmHg}$ with a p-value of 0.004 . The study that is done by Septianty (2015), mentioned that the average systolic pressure before the treatment is given is $147.63 \mathrm{mmHg}$, while after the treatment is given the number is reduced to $135.25 \mathrm{mmHg}$. On the other hand, the average diastolic pressure before lavender aromatherapy is given is $93.19 \mathrm{mmHg}$ and $83.00 \mathrm{mmHg}$ after the treatment is done with a p-value of 0.000 . Based on the explanation mentioned above, a researcher interested in studying the effectiveness of lavender aromatherapy on blood pressure among elderly with essential hypertension aim to understand the effect of lavender aromatherapy on the changes of blood pressure on essential hypertension patients.

Ramadhani, D. Y. (2022). The Effectiveness of Lavender Aromatherapy on Blood Pressure among Elderly with Essential Hypertension. The Journal of Palembang Nursing Studies. 1(1): 1-8. http://dx.doi.org/10.55048/jpns.v1i1.8 


\section{METHODS}

\section{Design}

This research was quantitative research using a pra-experiment pretest-posttest design where the blood pressure is measured twice which is before the lavender aromatherapy is given (pre-test) and after the lavender aromatherapy is given (post-test).

\section{Sample and Setting}

The population of this study is the total amount of hypertension patients in the Public Health Center in Jambi, Indonesia in 2018 which is 627 patients, while the sample of this study is the essential hypertension patients which are 15 patients With the sample used in this study is Purposive Sampling. The inclusion criteria in this study were Willing to be a research respondent, Can communicate verbally, No complications from other diseases, No impaired sense of smell, No drug consumption during the research process, Systolic blood pressure 140 and diastolic $90 \mathrm{mmHg}$, Hypertensive patients with age $>45$ year

\section{Variable}

The variable in this study is the blood pressure of hypertension patients. The dependent variable in this study was blood pressure and the independent variable was lavender aromatherapy

\section{Instruments}

In carrying out treatment, lavender aromatherapy is carried out with a module guide that has been made by researchers with the help of sources in the form of books on lavender aromatherapy, the equipment used in this study is a digital sphygmomanometer (digital Aneroid Sphignomanometer) which is used to measure the patient's blood pressure before and before performing the procedure. units $(\mathrm{mmHg})$, other equipment used is a steam diffuser, water and lavender aromatherapy in the form of essential oils.

\section{Intervention}

In this study, there was a one group pre-test and post-test design, with an intervention in the form of lavender aromatherapy. Performed for 6 days as much as 1 treatment in 1-day visit, carried out for 15 minutes Other equipment used was a steam diffuser, water and lavender aromatherapy in the form of essential oil as much as 5-6 drops each time treatment with a distance of $2-3 \mathrm{~cm}$, before and after given treatment, all respondents were checked for blood pressure on the first and sixth days which would be recorded on the observation sheet because the blood pressure data obtained before and after treatment would be analyzed univariate and bivariate.

\section{Data analysis}

This study used univariate analysis and bivariate analysis was carried out on two variables and was used to prove the existence of a significant relationship between the independent and dependent variables, which was carried out using the T-Test test

\section{Ethical Consideration}

This study uses humans as subjects, it must not be contrary to ethics, the purpose of the research must be ethical, meaning that the rights of respondents must be protected. In this study, the steps taken after obtaining the researcher's approval were asking permission to explain the purpose and benefits of the researcher and then asking for the willingness of the respondents to participate in the study, ethical issues in this study would be implemented such as research consent sheet, anonymous, confidentiality, privacy, fair treatment, self-determination.

\section{RESULTS}

Demographic data in this study are based on age, gender and occupation. It can be seen that the gender characteristics of the 15 respondents were 8 respondents $(53.3 \%)$ with male gender, 7 respondents $(46.7 \%$.) with the female gender. of the 15 respondents seen from the characteristics of age, as many as 9 respondents aged $45-59$ years (60\%). Based on 15 respondents viewed from the characteristics of the work, as many as 5 respondents with self-employed jobs (33.33\%), 5 respondents with retired jobs $(33.33 \%)$ and 5 respondents with housewife jobs (33.33\%).

Univariate Analysis aims to understand the frequency distribution from each variable that is being studied, which are blood pressure before the therapy is done and after the therapy is done.

\section{Blood Pressure before Lavender}

\section{Aromatherapy}

According to Table 1, the minimum value, 
Table 1. Illustration of Blood Pressure distribution before Lavender Aromatherapy

\begin{tabular}{lccccc}
\hline Variable & Mean & Min & Max & SD & $\mathbf{n}$ \\
\hline Pre-Test Sistole & 145.60 & 140 & 169 & 7.944 & 15 \\
Pre-Test Diastole & 92.00 & 90 & 100 & 4.140 & 15 \\
\hline
\end{tabular}

Table 2. Illustration of Blood Pressure distribution after Lavender Aromatherapy

\begin{tabular}{lccccc}
\hline Variabel & Mean & Min & Max & SD & $\mathbf{n}$ \\
\hline Post-Test Sistole & 136,93 & 120 & 160 & 9.004 & 15 \\
Post-Test Diastole & 83,87 & 80 & 99 & 6.081 & 15 \\
\hline
\end{tabular}

Table 3. Differences in blood pressure before and after the application of lavender aromatherapy

\begin{tabular}{lcc}
\hline Variable & $\begin{array}{c}\text { Pre Test Sistole } \\
\text { Post Test Sistole }\end{array}$ & $\begin{array}{c}\text { Pre Test Diastole } \\
\text { Post Test Diastole }\end{array}$ \\
\hline Z & $-3.468 \mathrm{a}$ & $-3.557^{\mathrm{a}}$ \\
Asymp. Sig. (2-tailed) & 0.001 & 0.000 \\
\hline
\end{tabular}

maximum value and standard deviation of the patient's systolic blood pressure before being given lavender aromatherapy (pre-test) is 145.60 and the patient's diastolic blood pressure after being given with lavender aromatherapy is 92.00 with the minimum systolic value of 140 and minimum diastolic value of 90 , the maximum systolic value of 169 and diastolic maximum value of 100 along with systolic standard deviation of 7.944 and diastolic standard deviation of 4.140.

\section{Blood Pressure after Lavender}

\section{Aromatherapy}

According to Table 2, the minimum value, maximum value and standard deviation of the patient's systolic blood pressure before being given lavender aromatherapy (posttest) is 136.93 and the patient's diastolic blood pressure after being given with lavender aromatherapy (post-test) is 83.87 with the minimum systolic value of 120 and minimum diastolic value of 80 , the maximum systolic value of 160 and diastolic maximum value of 99 along with systolic standard deviation of 9.044 and diastolic standard deviation of 6.081 .

\section{Differences in blood pressure}

\section{before and after the application of}

\section{lavender aromatherapy}

Table 3 showed that there are differences in blood pressure before and after the lavender aromatherapy is given. This showed that lavender aromatherapy gives a positive impact on blood pressure and could be used as an alternative complementary therapy to change blood pressure.

The effects of lavender aromatherapy to changes of blood pressure on Essential Hypertension patients. On the Statistics Test table above, $Z$ values of systole are $-3,468$, and 3,557 on diastole. On the other hand, the $Z$ Table Value is obtained from Table $Z$ with the alpha of $5 \%$ or 0.05 which value is around $-1,645$ (the negative marks are customized by output from $Z$ Count values). Whereas the Asymp. Sig value (2-tailed) is 0,001 on systole and 0,000 diastole. Because the value of $Z$ Count $>Z$ Table which is systole of $-3,468$, and diastole of $-3,557>-1,645$ or sug value 0,001 and $0,000<0,05$ which based on the statistic test, the $\mathrm{HO}$ will be rejected.

\section{DISCUSSION}

\section{Blood Pressure before Lavender}

\section{Aromatherapy}

Based on the results of the research that has been done, it is found that the description of blood pressure before Lavender Aromatherapy is carried out, namely the minimum, maximum and standard deviation values of systolic blood pressure in respondents before being given Lavender Aromatherapy (pre-test) is 145.60 and diastolic blood pressure in respondents after being given Lavender Aromatherapy 
(post-test) is 92.00. the minimum systolic value is 140 and the minimum diastolic value is 90 , the maximum systolic value is 169 and the maximum diastolic value is 100 . And the systolic standard deviation is 7,944 and the diastolic standard deviation is 4,140. This result is aligned with Suviani et al. (2014), the study which found that the average value of systolic blood pressure before the therapy given is $161,76 \mathrm{mmHg}$ and $94.44 \mathrm{mmHg}$ for diastolic. After the lavender aromatherapy is given, there is a decrease in average systolic blood pressure which is $149.99 \mathrm{mmHg}$ and average diastolic blood pressure of $85.98 \mathrm{mmHg}$.

Relaxation is related to the human nervous system which includes sympathetic and parasympathetic nerves. The relaxed condition could stimulate the body to produce a molecule which is usually called nitric oxide (NO), this molecule works on blood vein muscle so that they could reduce the blood pressure (Baradero et al., 2008). Aromatherapy is one of few traditional medicines that exist until now. This treatment has been going on for generations, so, naturally, the interest and response of the community to this method is increasing overtimes. Even though the method is relatively simple, it has several strengths compared to another method (Jaelani, 2017). One of the best ways to reduce blood pressure is by relaxation therapy. Studies showed that relaxation therapy that is being done regularly could reduce systolic and diastolic blood pressure, reduce the level of the stress hormone cortisol, reduce anxiety so that the blood pressure will decrease, and the body will function better.

\section{Blood Pressure after Lavender}

\section{Aromatherapy}

Based on the results obtained that the description of blood pressure before being given Lavender Aromatherapy, namely the value of the respondent after being given Lavender Aromatherapy (post-test) was 136.93 and diastolic blood pressure to the respondent after being given Lavender Aromatherapy (post-test) was 83.87. With a minimum systolic value of 120 and a minimum diastolic value of 80 , the maximum systolic value is 160 and the maximum diastolic value is 99 .

This result is also aligned with Suviani et al. (2014), the study which found that the average value of systolic blood pressure before the therapy given is $161,76 \mathrm{mmHg}$ and $94.44 \mathrm{mmHg}$ for diastolic. After the lavender aromatherapy is given, there is a decrease in average systolic blood pressure which is $149.99 \mathrm{mmHg}$ and average diastolic blood pressure of 85.98 $\mathrm{mmHg}$. In addition, Lubis (2009) stated that there is a significant decrease in systolic blood pressure value after the lavender aromatherapy is being given, from 4.95 to 4.15 .

Kim \& Kwon (2010), the study found a significant difference in pulse and blood pressure, primarily in the aromatherapy given experimental group compared with the controlled group that is not being given the aromatherapy. Adhistya et al. (2013), the study said that hypertension has a linear relation with morbidity and mortality of cardiovascular diseases. Aromatherapy is one relaxation technique that could be useful to handle hypertension, one of them is lavender aromatherapy, which could be given a relaxation effect and sedation that could reduce hypertension.

According to the study done by the researcher, blood pressure could be affected by many factors, one of which is lavender aromatherapy application. The results showed a significant decrease in average blood pressure from 147.63 to 135.25 and diastolic value from 93.19 to 83.00 . The average age of the respondents was below 50 years old, so it is assumed that primary hypertension that occurs is not yet being complicated. The researcher sees that the application of lavender aromatherapy had a fairly good influence on hypertension patients. Although the application is pretty good, a calm ambience in the surrounding is needed to achieve maximum results by creating a relaxing effect that will also affect the respondent's blood pressure change. Furthermore, the application of lavender therapy did not have any side effects, unlike pharmacological medicines.

Aromatherapy is one of few traditional medicines that exist until now. This treatment has been going on for generations, so, naturally, the interest and response of the community to this method is increasing overtimes. Even though the method is relatively simple, it has several strengths compared to another method (Jaelani, 2017). Hypertension is defined as persistent blood pressure which sees the systolic pressure above $140 \mathrm{mmHg}$ and diastolic pressure above $90 \mathrm{mmHg}$. Mild hypertension is where the diastolic pressure is around 95$104 \mathrm{mmHg}$. Whilst medium hypertension is when the diastolic pressure is between 105

Ramadhani, D. Y. (2022). The Effectiveness of Lavender Aromatherapy on Blood Pressure among Elderly with Essential Hypertension. The Journal of Palembang Nursing Studies. 1(1): 1-8.http://dx.doi.org/10.55048/jpns.v1i1.8 
$\mathrm{mmHg}$ and $114 \mathrm{mmHg}$. Severe hypertension is being categorized as a condition that sees diastolic pressure above $115 \mathrm{mmHg}$ or more. This definition is being defined by diastolic pressure because it has a more serious impact compared to systolic (Padila, 2013).

\section{The effect of lavender aromatherapy on blood pressure}

The results were obtained by correlation that the value of Asymp. Sig (2-tailed) was obtained at 0.001 systoles and 0.000 diastoles. Because Z count $>$ Z table, i.e. systolic -3.468 , and diastolic $-3.557>-1.645$ or sig values of 0.001 and $0.000<0.05$, then $\mathrm{HO}$ is rejected. From the research done in table 3 , it could be seen that respondent's number 1 did not experience a change in his diastolic blood pressure whereas the systolic blood pressure has. On the other hand, the lowest difference of blood pressure changes happened on respondent number 4 which is only 1 before and after the lavender aromatherapy is given.

According to the study done by Soraya (2014), on lavender aromatherapy effect on blood pressure decrease in elders with hypertension at Kelurahan Siantan Hulu, Pontiakan Utara, it is found that the average systolic and diastolic blood pressure before the lavender aromatherapy is being applied is $154.44 \mathrm{mmHg}$ and $95 \mathrm{mmHg}$ respectively. Whilst the average systolic and diastolic blood pressure after the lavender aromatherapy applied is $138.89 \mathrm{mmHg}$ and $85 \mathrm{mmHg}$ respectively, with a p-value of 0.004 .

Blood pressure is the number of types of blood that is pushed to the arterial wall (blood vessels) when the heart pumped blood throughout the human body. A healthy Adult's Systolic blood pressure is between 90 and 120 millimetres of mercury $(\mathrm{mmHg})$. Diastolic normal blood pressure is between 60 and $80 \mathrm{mmHg}$ (Wade, 2016). Hypertension was a condition when someone experienced an increase in blood vessels above normal that could result in morbidity and mortality. Blood pressure of $140 / 90 \mathrm{mmHg}$ is based on 2 phases of every heartbeat which is the systolic phase of 140 that shows the phase of blood that is being pumped by the heart and the diastolic phase of 90 which showed returning blood phase to the heart (Triyanto, 2014).

Hypertension treatment is aimed to prevent morbidity and mortality caused by a cardiovascular complication that relates to achievement and maintenance of blood pressure below 140/90 (Padila, 2013). Hypertension is a condition where the blood pressure is continuously increasing abnormally which is caused by one or more risk factors that did not work properly to maintain normal blood pressure (Andra \& Yessie, 2013). Lavender aromatherapy is a method of body or disease treatment that uses essential oil. Lavender aromatherapy could soothe people physically and emotionally. The benefits of lavender aromatherapy include reducing anxiety, joint pain, high blood pressure, heart frequency, metabolic rate, insomnia, stress, and increased melatonin and serotonin. Aromatherapy is a method of therapy that uses evaporating oil or essential oil with a human's olfactory organ (Jaelani, 2017).

The content of lavender aromatherapy triggers olfactory nerve cells and affect the limbic system which results in a relaxed feeling that affects the blood pressure. The administration of lavender aromatherapy for 15 minutes could affect the limbic system and cause a relaxation effect which made the heart works slower in pumping blood throughout the body and lowering the blood pressure of the respondent. The effect of aromatherapy is positive because of its fresh and fragrant scent which triggers human's sensory and caused an effect in organs that resulted in a strong effect on emotion (Jaelani, 2017).

Based on the research result, it could be concluded that there's an effect caused after lavender aromatherapy treatment is given six times to elderly with hypertension. Therefore, it's strongly suggested to people who are diagnosed with hypertension to use this therapy as one intervention because this complementary therapy is very safe and has a positive effect. The aim of hypertension treatment is not only to decrease blood pressure but also so patients could become stronger. Hypertension treatment generally needs to be given for life, hence it's better to do treatment using complementary therapy.

\section{CONCLUSION}

Based on the research result explanation, it could be concluded that Statistical test result shows there is a significant effect in blood pressure of patients with essential hypertension after lavender aromatherapy based on the results obtained that there is an effect of giving lavender aromatherapy with blood pressure as

Ramadhani, D. Y. (2022). The Effectiveness of Lavender Aromatherapy on Blood Pressure among Elderly with Essential Hypertension. The Journal of Palembang Nursing Studies. 1(1): 1-8. http://dx.doi.org/10.55048/jpns.v1i1.8 
evidenced by $p<0.05$ with a systolic $p$-value $=0.001$ and a diastolic $p$-value $<0.000$. It is suggested that Public Health Care in Jambi and other cities or provinces use lavender aromatherapy as an alternative treatment to decrease the blood pressure of patients with essential hypertension. Puskesmas could educate the public regarding lavender aromatherapy.

\section{Declaration of Interest}

None

\section{Acknowledgment}

I would like to thank to the respondents who participated in the study.

\section{Funding}

None

\section{Data Availability}

The datasets generated during and/or analyzed during the current study are available from the corresponding author on reasonable request.

\section{REFERENCES}

Adhistya, M., Wowor, M., \& Hamel, R. S. (2013). Pengaruh Pemberian Aromaterapi Lavender (Lavandula Angustifolia) Terhadap Penurunan Tekanan Darah Pasien Hipertensi Di Irina F RSUP. Prof. Dr. Rd Kandou Manado. E-NERS, 1(1). https://doi.org/10.35790/ens.v1i1.1780

Andra, S. W., \& Yessie, M. P. (2013). KMB 1 Keperawatan Medikal Bedah Keperawatan Dewasa Teori dan Contoh Askep. In Yogyakarta: Nuha Medika.

Arinkunto, S. (2002). Prosedur penelitian suatu pendekatan praktek. Jakarta: PT Rineka Cipta.

Baradero, M., Dayrit, M. W., \& Siswadi, Y. (2008). Prinsip dan praktik Keperawatan perioperatif. Jakarta: EGC.

Barbara, K., \& Erb, G. (2010). Buku Ajar Fundamental Keperawatan: konsep, proses, dan praktik. Jakarta: EGC.

Bustan, M. N. (2015). Manajemen pengendalian penyakit tidak menular. Jakarta: Rineka Cipta.

Efendi, F., \& Makhfudli, M. (2009). Keperawatan Kesehatan Komunitas: teori dan praktik dalam keperawatan. Jakarta: Salemba Medika.

Herliawati, H., \& Ramadhani, R. (2014). Pengaruh Masase Kaki Dengan Minyak
Esensial Lavender Terhadap Penurunan Tekanan Darah Penderita Hipertensi Primer Usia 45-59 Tahun Di Kelurahan Timbangan Kecamatan Indralaya Utara Kabupaten Ogan Ilir. EPrints UNSRI, 1(3).

Infodatin. (2016). Situasi Lanjut Usia (Lansia) Di Indonesia. Infodatin Kementerian Kesehatan RI. https://pusdatin.kemkes. go.id/article/view/16092300002/ infodatin-situasi-lanjut-usia-lansia-diindonesia.html

Jaelani. (2017). Aroma Terapi. Jakarta: Pustaka Populer Obor.

Kim, M., \& Kwon, Y. J. (2010). Effects of aroma inhalation on blood pressure, pulse, visual analog scale, and McNair scale in nursing students practicing intravenous injection at the first time. International Journal of Advanced Science and Technology, 23(2), 61-68.

Koesoemardiyah, A. Z. (2012). Aromaterapi: untuk kesehatan kebugaran dan kecantikan. Yogyakarta: Andi. Monika, B.

Kusyati, E., Santi, N. K., \& Hapsari, S. (2018). Kombinasi relaksasi napas dalam dan aroma terapi lavender efektif menurunkan tekanan darah. Prosiding Seminar Nasional Unimus, 1.

Lestari, D., Udiyono, A., Saaraswati, L. D., \& Adi, M. S. (2018). Gambaran Fungsi Kognitif Pada Penderita Hipertensi Usia 45-59 Tahun Di Puskesmas Tlogosari Wetan Kota Semarang. Jurnal Kesehatan Masyarakat (Undip), 6(1), 207-214.

Lubis. (2009). Effect of Lavender Essential Oil Aromatherapy on Recovery Time of Blood Pressure and Pulse Rate after Rhyming Test among Padjadjaran University Medical Students. The Indonesian Journal of Physiology, 8, 71-142.

Muttaqin, A. (2008). Pengantar asuhan keperawatan klien dengan gangguan sistem persarafan. Jakarta: Salemba Medika.

Notoatmodjo, S. (2012). Metedeologi Penelitian Kesehatan. Jakarta: Rineka Cipta.

Padila. (2013). Asuhan Keperawatan Penyakit Dalam. Yogyakarta: Nuha Medika.

Perry, A. G., \& Potter, P. A. (2005). Buku Ajar Fundamental Keperawatan; Konsep, proses, dan praktik. Volume 1. Jakarta: EGC.

Prastyo, D. (2014). Faktor Risiko Penyakit Hipertensi pada Laki-laki Usia Produktif

Ramadhani, D. Y. (2022). The Effectiveness of Lavender Aromatherapy on Blood Pressure among Elderly with Essential Hypertension. The Journal of Palembang Nursing Studies. 1(1): 1-8.http://dx.doi.org/10.55048/jpns.v1i1.8 
di Wilayah Kerja Puskesmas Bangsal Kabupaten Mojokerto.

Price, S., \& Price, L. (2011). Aromatherapy for health professionals E-book. USA: Elsevier Health Sciences.

Rakhmawati, R., Putra, K. R., \& Perdana, F. R. B. P. B. (2014). Metode Keperawatan Komplementer Hipnoterapi Untuk Menurunkan Efek Stress Pasca Trauma Tingkat Sedang Pada Fase Rehabilitasi Sistem Penanggulangan Kegawatdaruratan Terpadu (SPGDT). Jurnal Keperawatan, 5(2), 178-184.

Riskesdas. (2018). Prevalensi Jumlah Penyakit Hipertensi Berdasarkan Provinsi. KementerianKesehatanBadanPenelitian Dan Pengembangan Kesehatan. https:// kesmas.kemkes.go.id/assets/upload/ dir_519d41d8cd98f00/files/Hasilriskēesdas-2018_1274.pdf

Septianty, L. (2015). Fektivitas Pemberian Aromaterapi Lavender Terhadap Pengukuran Tekanan Darahpada Pasien Hipertensi Di Klinik Pratama Universitas
Tanjungpura. Jurnal ProNers, 3(1).

Soraya, U. (2014). Pengaruh Aromaterapi Lavender Terhadap Penurunan Tekanan Darah Pada Lansia Dengan Hipertensi Di Kelurahan Siantan Hulu Pontianak Utara. Jurnal ProNers, 3(1).

STIKBA. (2015). Pedoman penulisan skripsi. Jambi: Sekolah Tinggi Ilmu Kesehatan Baiturahim.

Suviani, N. W., Artana, I. W., \& Putra, P. W. K. (2014). Pengaruh pemberian aroma terapi lavender (lavandula angustifolia) terhadap penurunan hipertensi pada lansia di Desa Cemagi, Kecamatan Mengwi, Kabupaten Badung. Jurnal Dunia Kesehatan, 3(1), 31-35.

Syamsudin. (2011). Buku Ajar Farmakoterapi Kardiovaskular Dan Renal. Jakarta: Salemba Medika.

Triyanto, E. (2014). Pelayanan keperawatan bagi penderita hipertensi secara terpadu. Yogyakarta: Graha IImu.

Wade. (2016). Mengatasi Hipertensi. Bandung: Nusa Cendekia.

Ramadhani, D. Y. (2022). The Effectiveness of Lavender Aromatherapy on Blood Pressure among Elderly with Essential Hypertension. The Journal of Palembang Nursing Studies. 1(1): 1-8. http://dx.doi.org/10.55048/jpns.v1i1.8 